\title{
Influence of Sawmill Industries on the Health of Sawmill Workers and Inhabitant of the Environment in Ondo State Nigeria
}

\author{
Akinnubi Caroline Funmbi (Ph.D) \\ Department of Physical and Health Education, Faculty of Educaton, Obafemi Awolowo University lle Ife Nigeria \\ fakinnubi @yahoo.com
}

\section{Doi:10.5901/jesr.2015.v5n2p299}

\begin{abstract}
This study examined the influence of sawmill wastes on health among the sawmill workers and inhabitants of the environment in Ondo State Nigeria. A total of 240 respondents consisting of 110 sawmill workers and 130 inhabitants of residential areas around sawmills were drawn using accidental sampling technique. A validated self-structured questionnaire with reliability coefficient of 0.85 was used for the study. The data collected were analyzed using simple percentages and inferential statistics of $t$-test analysis. The findings of the study revealed that the respondents did not have knowledge and experience about the importance of health education, the safety gadgets, protective devices and environmental health aids equipment were not adequate, there was a significant difference in the awareness of wastes generated in the sawmills between the sawmill workers and the inhabitant of the residential areas, a significant difference in the awareness of diseases contracted in sawmills that can affect health, and a significant difference in the excessive exposure to loud noise. It is therefore recommended that wastes should not be burnt. Sawmills operators should be provided with protective shield and gloves, and be monitored to wear them regularly. First aid box and toilets should be provided.
\end{abstract}

Keywords: Assessment, Sawmill Wastes, Health, Sawmill Workers, Inhabitant of the Environment

\section{Introduction}

Sawmill can be said to be one of major industries in Nigeria because it is located in every nooks and corners particularly in southwestern states of Nigeria in which Ondo State is one. Sawmill is a factory where wood is cut into planks or boards in various sizes and shapes through the process of sawing by machine (Microsoft Encarta Dictionary 2009, Omobude-Idiado, Irimonre, \& Ohi-Asikhia 2013). Akachukwu, (2000) posited that the first power- driven sawmill was installed at the beginning of the 20th century.

Sawmill generates various wastes such as; saw dusts, wood off cuts, wood backs, plain shavings and wood rejects (Dosunmu and Ajayi, 2002, Akinbode and Olujimi 2014). One of the most environmental problems facing the industry, in this jet age is the improper disposal of waste generated often in the sawmill industries (Akinbode \& Olujimi 2014). Occupation and health interact with one another (Lucas and Gillies 2003). It is no gainsaying therefore that a man's occupation may influence his health. (Omobude-Idiado, Irimonre, \& Ohi-Asikhia 2013). Saw millers use several crude ways to dispose the generated wastes within the vicinity of sawmills and plank markets (Lasode, Balogun \&Aremu 2009). Amunega (2002) explained that occupational activities have been found to be creating ecological and environmental problems that are having adverse effects on the health and well-being of people. Physical condition in the workplace such as prolonged loud and vibration are caused by tools and machinery (Odukogbe, 1995).

World Health Organization (WHO 1985), explained that some of the risks associated with factory workers are industrial poisons, radiation, hyperbaric, noise, psychosocial stress and physical injuries. Cherry (2001) stressed that when workers are not provided with safety gadgets, they are exposed to health hazards. The problems posed by wastes generated in sawmill are many. They degrade the urban environment, thereby reduce its aesthetic value, and create offensive odours during the rains and contaminate the air with smoke when the wastes are burnt without controll. They also constitute health hazards when they are not timely disposed. They also pose bad working environment for those working in the area, due to accumulation of wastes over a period of time most especially during raining season and also constitute health hazard (Odewumi 2001, Akinbode \& Olujimi 2014).

According to Awake (2005), the pollution of the first industrial revolution led to severe environmental degradation in several parts of the United States in the two decades. Dosunmu and Ajayi, (2002) explained that exposure to excessively loud noise from sawmill machines such as the CDC band saw over long periods can lead to partial deafness. According 
to Theodore and Hattington (1981) as stated by Amunega (2002), there is lack of adequate knowledge and experience about the importance of health education within industry. Pollution has been defined by Akachukwu, (2000) as phenomena where natural ingredients are replaced or damaged by presence of dangerous unnatural ingredients - which have potentiality to cause imbalance to the system and to create number of health hazards to animals and human beings. According to Foster (1995) as stated by Adeniyi (2002), Occupational physical hazards include noise, heat, light, radiation, vibration, temperature, and pressure that can produce lots of problems with adequate exposure of workers to such conditions.

Noise pollution is a disturbing and unwanted sound/noise, which is created by airplanes, heavy traffic, or industrial machines such as in sawmills (Microsoft Encarta 2009). In a study conducted by Ehor and Onohwakpor (2002), it was observed that workers in the Delta Glass Plc are aware of and are exposed to health hazards. Many workers are exposed to a lot of hazards and risks at work (Omobude-Idiado, Irimonre, \& Ohi-Asikhia 2013). In a study conducted by Adegbenro and Fabiyi (2002) headache /fever topped the list of health problems experienced by the workers with $90 \%$ while hearing problem was experienced among the workers with 25\%. According to Nwajei \& Nwanchukwu (2002), injuries, diseases and deformities multiplied among the industrial workers. They suffered in silence as medical services were not readily provided. Employers did not take the interest or welfare of their employees seriously.

Ehor and Onohwakpor (2002) concluded that the prime responsibility for occupational safety and health lies with the employers. While according to Amunega (2002), for preventive measures, first aid box must be provided to cater for the emergency needs of the workers likewise protective shield by the employers. In the study conducted by Adeogun \& Idowu (2002), it was found that protective devices and safety gadgets were not adequately provided for workers and this is capable of exposing them to hazards and health risks.

According to Ezeji and Onoh (2008) Safety could be defined as planned measures or precautions that should betaken to control situations and acts in an endeavour to prevent injuries to the persons concerned, injuries to others who may be around the working place and damage to workshop equipment and materials. Amunega (2002) said safety is a state of not being in danger or harm. According to Gray (1990), safety is a condition of being free from danger of injury and as a legal concept. According to Odukogbe 1995 as stated by Adeogun and Idowu (2002), safety education in industries save a lot of things raging from wastage of human and material resources, increase volume of safety education at work, calls for absolute commitment by both the employee and the employer. In a study conducted by Anaele, Adelakun and Olumoko (2014) it was found that safety practice skills are needed by the sawmill workers for effective and functional operations against workplace hazards.

\section{Objectives of the Study}

The following are the specific objectives necessary for the study;

Assess the knowledge and experience about the importance of health education, the adequacy of the safety gadgets/ protective devices and environmental health aids equipment.

Determine awareness of wastes generated and diseases contracted in sawmills that can affect health, and the excessive exposure to loud noise from equipment and facilities between the sawmill workers and the inhabitant of the residential areas.

\section{Research Questions}

(1) Do you have knowledge and experience about the importance of health education?

(2) Were the safety gadgets/ protective devices and environmental health aids equipment (first aid box) adequate in the sawmill you work?

Research Hypotheses

(1) There is no significant difference in the awareness of wastes generated in sawmills between the sawmill workers and the inhabitant of the residential areas.

(2) There is no significant difference in the awareness of diseases contracted in sawmills that can affect health by sawmill workers and the inhabitant of the residential areas.

(3) There is no significant difference in the excessive exposure to loud noise from equipment and facilities used in sawmill between the sawmill workers and the inhabitant of the residential areas. 


\subsection{Research Method}

Descriptive survey research design was used for this study. This type of design according to Sanni (2002) as stated by Oladipupo-Okorie \& Adeyeye (2012) is best used to gather, organize, present and analyze data for the purpose of describing the occurrence of an event or phenomenon within a particular people. Therefore it is the best method that could be adopted for this research design because it described the situation as it is. The population of the study consisted of 8 sawmills in Ondo State. However, 240 respondents consisting of 110 sawmill workers and 130 inhabitants of the environment who were within the age range of 20-60 years. These respondents were selected using accidental sampling techniques. A self structured questionnaire was used to collect data on the sawmill wastes on health among the sawmill workers and inhabitant of the environment. The questionnaire tagged (SWH) contained two Sections, Section A of the questionnaire dealt with the demographic characteristics of respondents, while section B consisted of four sections which was developed on 'Agreed'/'Disagreed' and Adequate/ Inadequate, an alternative responses that elicited information regarding the awareness of wastes generated in sawmills, available safety and environmental health aid equipment, prevalent of diseases, and the vibration level of equipment used. The questionnaire was validated by experts. The reliability of the instrument was established using the test-retest method on similar group from another sawmill which yielded an index of 0.85 . The data for the study was gathered through the distribution of the questionnaire to the 240 respondents personally with the help of three research assistants and the filled questionnaires were collected back on the spot. Data collected were coded and analyzed using frequency distribution, simple percentages and inferential statistic of t-test. Inferences were made at 0.05 alpha level.

\subsubsection{Results And Discussion}

Table 1: Bio-social characteristics of the respondents

\begin{tabular}{|lcc|}
\hline Characteristics & $\begin{array}{c}\text { Frequency (f) } \\
\text { Location }\end{array}$ & Percentages (\%) \\
Sawmill Workers & 110 & $45.8 \%$ \\
Inhabitants of the Environment & 130 & $54.2 \%$ \\
Total & 240 & $100 \%$ \\
\hline 20-30 years & Age & $15.8 \%$ \\
31-40 years & 38 & $34.6 \%$ \\
41-50 years & 83 & $34.6 \%$ \\
$51-60$ years & 83 & $15 \%$ \\
Total & 36 & $100 \%$ \\
\hline Sex & 240 & $45(18.8 \%)$ \\
Male & Sawmill Workers & $85(35.4 \%)$ \\
Female & $78(32.5 \%)$ & $130(54.2 \%)$ \\
Total & $32(13.3 \%)$ & Inhabitants of the Environment \\
\hline
\end{tabular}

\subsubsection{Research Question 1: Do you have knowledge and experience of the importance of Health Education?}

Table 2: Descriptive and percentage analysis of knowledge and experience of the importance of health education?

\begin{tabular}{|c|c|c|c|c|}
\hline No & Location & Agreed \% & Disagreed & Total \\
\hline 1. & Sawmill workers & $8 \quad(3.3 \%)$ & $102(42.5 \%)$ & $110(48.2 \%)$ \\
\hline 2. & Inhabitants of the Environment & $10 \quad(4.2 \%)$ & $120(50 \%)$ & $130(54.2 \%)$ \\
\hline & Total & $18(7.5 \%)$ & $222 \quad(92.5 \%)$ & $240(100 \%)$ \\
\hline
\end{tabular}

Table 2 shows that, 8 (3.3\%) sawmill workers and 10 (4.2\%) inhabitants of the Environment signified that they had knowledge and experience of the importance of health education. While a greater proportion of $102(42.5 \%)$ sawmill workers and $120(50 \%)$ inhabitants of the Environment said that they never had knowledge and experience of the importance of health education. This is similar to Theodore and Hattington (1981) as stated by Amunega (2002), who said there is lack of adequate knowledge and experience about the importance of health education within industry. 


\subsubsection{Research Question 2: Were the safety gadgets/ protective devices and environmental health aids equipment (first} aid box) adequate in the sawmill you work?

Table 3: Descriptive and percentage analysis of the adequacy of safety gadgets/ protective devices and environmental health aids equipment (first aid box) in the sawmill you work

\begin{tabular}{|c|c|c|}
\hline \multirow{2}{*}{ Variables } & \multicolumn{2}{|c|}{ Sawmill workers } \\
\hline & Adequate $\%$ & Inadequate $\%$ \\
\hline Protective device/clothing & $24 \quad(21.8 \%)$ & $86 \quad(78.2 \%)$ \\
\hline Fire extinguish & $35(31.8 \%)$ & $75 \quad(68.2 \%)$ \\
\hline $\begin{array}{l}\text { First aid box } \\
\end{array}$ & $38 \quad(34.8 \%)$ & $72 \quad(65.2 \%)$ \\
\hline Well/ tap/ borehole/ or overhead tank water & $20 \quad(18.2 \%)$ & $90(81.8 \%)$ \\
\hline Incinerator & $11(10 \%)$ & $99 \quad(90 \%)$ \\
\hline Toilets & $20 \quad(18.2 \%)$ & $90(81.8 \%)$ \\
\hline
\end{tabular}

Table 3 shows that very few of the respondents did agree that safety gadgets/ protective devices and environmental health aids equipment (first aid box) above such as protective device/clothing, fire extinguish, first aid box, well/tap/borehole/or overhead tank water, incinerator, and toilets were adequate for use, while many of the respondents disagreed that gadgets/ protective devices and environmental health aids equipment (first aid box) above were adequate for use in the sawmill. This is in line with the earlier researchers, Adeogun \& Idowu (2002), who found in the study conducted that protective devices and safety gadgets were not adequately provided for workers and this is capable of exposing them to hazards and health risks.

\subsubsection{Hypothesis 1: There is no significant difference in the awareness of wastes generated in sawmills between the sawmill workers and the inhabitant of the residential areas.}

\section{Table 4}

\begin{tabular}{|c|c|c|c|c|c|c|c|}
\hline Awareness & $\mathrm{N}$ & Mean & StD & Df & t-cal & t-critical & Decision \\
\hline Sawmill workers & 110 & 9.642 & 1.723 & \multirow{2}{*}{94} & \multirow{2}{*}{2.352} & \multirow{2}{*}{1.260} & \multirow{2}{*}{$\mathrm{S}$} \\
\hline Inhabitants of the residential areas & 130 & 9.345 & 1.521 & & & & \\
\hline
\end{tabular}

$P<=0.05$

The result on table 4 shows that the value of $t$-calculated value (2.352) is greater than the $t$-critic $(\mathrm{t}$-cal $=2.352$, $\mathrm{t}$ critic=1.260. $P<=0.05)$. Therefore, the null hypothesis was hereby rejected. This implied that the sawmill workers and the inhabitants of the residential areas were aware that the saw mill generates wastes but not in the same proportion. This is line with Dosunmu and Ajayi, (2002), Akinbode and Olujimi (2014), who stated that Sawmill generates various wastes such as; saw dusts, wood off cuts, wood backs, plain shavings and wood rejects.

Table 5: Descriptive and percentage analysis of the awareness of diseases contracted in sawmills that can affect health by sawmill workers and the inhabitant of the residential areas

\begin{tabular}{|c|c|c|c|c|}
\hline \multirow{2}{*}{ Variables } & \multicolumn{2}{|c|}{ Sawmill workers (110) } & \multicolumn{2}{|c|}{ Inhabitant of the residential areas. (130) } \\
\hline & Agreed\% & Disagreed \% & Agreed $\%$ & Disagreed \% \\
\hline Headache, & $98(40.8 \%)$ & $12(5 \%)$ & $94 \quad(39.2 \%)$ & $\begin{array}{ll}36 & (15 \%) \\
\end{array}$ \\
\hline Respiratory illness & $86(35.8 \%)$ & $24(10 \%)$ & $20(8.4 \%)$ & $110 \quad(45.8 \%)$ \\
\hline Cardio-vascular illness, & $48(20 \%)$ & $62(25.8 \%)$ & $14(5.8 \%)$ & $116(48 \%)$ \\
\hline Cough & $71(29.6 \%)$ & $39(16.25 \%)$ & $100(41.7 \%)$ & $30 \quad(12.5 \%)$ \\
\hline cancer risk & $0 \quad(0 \%)$ & $110(45.8 \%)$ & $0(0 \%)$ & $(54.2 \%)$ \\
\hline stomach upset/ nausea & $46(19.2 \%)$ & $64(26.7 \%)$ & $24(10 \%)$ & $(44.2 \%)$ \\
\hline skin irritation & $81(33.8 \%)$ & $29(12.1 \%)$ & $25(10.4 \%)$ & $(43.8 \%)$ \\
\hline Eye problem & $26(10.8 \%)$ & $84(35 \%)$ & $19(7.9 \%)$ & $(46.3 \%)$ \\
\hline body pains/ fever & $89(37 \%)$ & $21(8.8 \%)$ & $102(42.5 \%)$ & $(11.7 \%)$ \\
\hline hearing problem & $94 \quad(39.2 \%$ & $16(6.7 \%)$ & 96 (40\%) & $(14.2 \%)$ \\
\hline
\end{tabular}


Table 5 shows that 98(40.8\%) sawmill workers and 94(39.2\%) inhabitant of the residential areas agreed that they were aware that headache can be contracted in the sawmill due to noiose pollution. while 89 (37\%) sawmill workers and 102 (42.5\%) inhabitant of the residential areas agreed to body pains/fever. This is similar to a study conducted by Adegbenro and Fabiyi (2002) who observed that headache /fever topped the list of health problems experienced by the workers with $90 \%$ in industry. A total of 94 (39.2\%) sawmill workers and $96(40 \%)$ inhabitant of the residential areas signified that hearing problem can be contracted due to excessively loud noise. This is contrary to Adegbenro and Fabiyi (2002) who observed that only $25 \%$ out of $100 \%$ of the industrial workers experienced hearing problem. But in line with Awake (2001), who stated that noise pollution does negatively affect human being and the environment. None of the respondents both from the sawmill workers and inhabitant of the residential areas agreed that cancer risks can occur due to sawmill wastes. Eighty one sawmill workers out of 110 said; skin irritation is a problem among sawmillers. This is contrary to a study conducted by Omobude-Idiado, Irimonre, and Ohi Asikhia, (2013), who found out that skin problem is not a common health problem among samillers.

\subsubsection{Hypothesis 2: There is no significant difference in the awareness of diseases contracted in sawmills that can affect} health by sawmill workers and the inhabitant of the residential areas

Table 6

\begin{tabular}{|c|c|c|c|c|c|c|c|}
\hline Diseases experienced & $\mathrm{N}$ & Mean & Std & df & t-cal & t-critical & Decision \\
\cline { 1 - 6 } Sawmill workers & 110 & 7.563 & 1.221 & \multirow{2}{*}{94} & \multirow{2}{*}{2.171} & \multirow{2}{*}{1.260} & \multirow{2}{*}{$\mathrm{S}$} \\
\hline Inhabitant of the residential areas & 130 & 7.934 & 1.423 & & &
\end{tabular}

$$
\mathrm{P}<=0.05
$$

The result on table 6 reveals that there is a significant difference in the awareness of diseases contracted in sawmills that can affect health by sawmill workers and the inhabitant of the residential areas. This was revealed by the value of tcalculated value (2.171) which is greater than the $t$-critic $(t-c a l=2.171, t-c r i t i c=1.260 . P<=0.05)$. The null hypothesis is therefore not accepted.

3.1.6 Hypothesis 4: There is no significant difference in the excessive exposure to loud noise from of equipment and facilities used in sawmill between the sawmill workers and the inhabitant of the residential areas.

\section{Table 7}

\begin{tabular}{|c|c|c|c|c|c|c|c|}
\hline Vibration level of equipment and facilities & $\mathrm{N}$ & Mean & Std & Df & t-cal & t-critical & Decision \\
\cline { 1 - 5 } Sawmill workers & 65 & 9.773 & 1.133 & \multirow{2}{*}{94} & \multirow{2}{*}{2.382} & \multirow{2}{*}{1.260} & $\mathrm{~S}$ \\
\hline Inhabitant of the residential areas & 55 & 9.591 & 1.147 & & & & \\
\hline
\end{tabular}

The result on table 7 revealed that there is a significant difference in the excessive exposure to loud noise from of equipment and facilities used in sawmill between the sawmill workers and the inhabitant of the residential areas. This was indicated by the value of $\mathrm{t}$-calculated value (2.352) which is greater than the $\mathrm{t}$-critic $(\mathrm{t}$-cal $=2.352, \mathrm{t}$-critic $=1.260$. $\mathrm{P}<=0.05)$. This implied that although the respondents from the two locations were exposed to excessive loud sound/noise but their exposure was not alike

\section{Conclusion}

Based on the findings of this study, the following conclusions were made:

Majority of the sawmill workers and inhabitants of the residential areas agreed that they were awareness of diseases such as headache, Cough, body pains/ fever and hearing problem contracted in sawmills that can affect health. Safety gadgets/ protective devices and environmental health aids equipment (first aid box) were not adequate,

There was a significant difference in the awareness of wastes generated in sawmills between the sawmill workers and the inhabitant of the residential areas, a significant difference in the in the awareness of diseases contracted in sawmills that can affect health and a significant difference in the excessive exposure to loud noise from equipment and facilities used in sawmill. 


\section{Recommendation}

Based on the findings of this research, the following recommendations were made:

1) The Sawmills' authority should;

(a) make sure that wastes are not be burnt during windy time, as this can affect health, operating equipment and facilities used should not be too noisy because this can cause hearing defects, equipment and facilities operators should always be provided with protective shield and gloves and monitored to wear them regularly by the employers, first aid box should be provided by the sawmill authority for temporary remedy in case of emergency, toilets and good water should also be provided by the employers.

(b) show concern for their workers and the inhabitants around their premises in terms of their disposal of wastes.

2) The state and federal government should monitor sawmills through the environmental health officers to know that they are in good condition and conducive for working, and to organise seminar on how to protect their health

3) The workers and the inhabitants of the sawmill environment should be advised to visit the hospital regularly for medical check up by the government through seminar and media.

\section{Refrences}

Adegbenro C. A., \& Fabiyi a.k.,2002 Health Hazards among Workers in a Saw-Mill Industries in Bodija Market Ibadan Nigerian School Health Journal 1\&2, 123-132

Adeniyi J.A.(2002). Occupational Health and Safety: Concepts, Objectives and Relevance.Nigerian School Health Journal vol.14 1\&2, 190-199

Adeogun J.O. and Idowu B.B. (2002) On the Job Safety Assessment in Food Processing Industry: A Case Study of Nestle Nigeria PLC Nigerian School Health Journal 4, 1\&2 18-24

Akachukwu, A.E. (2000). Sawmilling waste in Nigeria and its effects on the environment, The Nigerian Field. 65: 219-223.

Akinbode T. and Olujimi Julius A.B. (2014) Effects of Sawmill Wastes in Residential Areas of Ogbose and Akure Townships, Ondo Sstate, Nigeria. International Journal of Innovation and Scientific Research, ISSN 2351-8014 Vol. 9 No. 2 Sep. 2014, pp. 399409 http://www.ijisr.issr-journals.org/

Amunega S. Bankole. (2002). Occupational Hazards in Odo-Okun Sawmill in Ilorin West Local Government Area of Kwara State: Causes and Prevention Nigerian School Health Journal 14, 1\&2 25-33

Anaele E.O., Adelakun O.A., \& Olumoko B.A. (2014), Re-engineering Technical Vocational Education and Training (TVET) towards Practice Skill Needs of Sawmill Workers against Workplace Hazards in Nigeria. Journal of Education and Practice ISSN 2222288X (Online) 5, 7 150-157

Awake, (2005): "Can Planet Earth Be Save" Watch Tower Bible and Tract Society of Pennsylvania, January 8, 2008, Vol. 86, No.1, 3-13.

Cherry, N. (2001); Handymen risk low sperm count. Journal of Occupational and Environmental Medicine. 14, 2

Dosunmu, O.O., and Ajayi A.B. (2002); Problem and management of sawmill waste in Lagos, Proceeding of International Symposium on Environmental Pollution Control and Waste Management, Tunis (EPCOWM 2002), PP 271-278.

Ehor L.O. and Onohwakpor, A.E.O. (2002) Occupational Health Harzards and Safety Measures in Delta Glass PLC. Ughelli Delta State. Nigerian School Health Journal 14, 1\&2, 99-113

Ezeji, S. C. O. A. \& Onoh, B. C. E. C. (2008). Construction Management. Enugu: Cheston Agency Press Ltd.

Foster, A. (1995); The effects of work on health. In M. Bamford (Ed.) Work and Health: An introduction to Occupational Health Care London Champman Hall.

Gray J.E. (1990): PLANNING health Promotion at the worksite Indianapolis: Benchmark Press.

Lasode O. A., Balogun A. O. \& Aremu A. S. (2009) Generation, Management Challenges and Prospects of Wood Waste in llorin, Nigeria. http://cere.udc.edu/Aina.pdf Date accessed: 1st August, 2013.

Lucas, A.O., \& Gilles, H. M., ( 2003) short textbook of public health medicine for tropics. London:Arnold Publishers

Microsoft Encarta Dictionary (2009) C 1993-2008 Microsoft Corporation. All right Reserved.

Nwajei S.D. \& Nwanchukwu,A.E.2002 Health and Safety Education as Essential Strategies in Prevention of Industraial Hazards. Nigerian School Health Journal vol. 14, 1\&2, 157-165

Odebunmi, S. G. (2001), "Solid Waste Transportation in Lagos State: Developing a Sistainable Model". Ph.D. Seminar,University of Lagos, Lagos. Nigeria.

Odukogbe, O.A. 1995. Safety Regulations in Nigerite PLC. Apaper presented at the seminar orghanized for Nirite Industry PLC. Unplished.

Omobude-Idiado, S.N., Irimonre, E.L., and Ohi Asikhia, M., (2013), Occupational Health Hazards in Sawmill Industries in Benin City.

Oladipupo-Okorie \& Adeyeye (2012) Theodore B. \& Harrington, J. 1981, Accident Prevention Campaign in major Greek Industry: International Journal of Health Education 24, 2

World Health Organisation (1985) "Expert Committee Report on Occupational Health" 